\title{
Treatment of a tooth with severe periodontal involvement using intentional replantation: case report
}

\author{
Youn-Kyung Choi', Kyoung-Hwa Jung', Ju-Youn Lee², Ji-Young Joo², Hyun-Joo Kim², Eun-Young Kwon * \\ 'Dental Clinic Center, Pusan National University Hospital, Busan, Republic of Korea \\ ${ }^{2}$ Department of Periodontology, School of Dentistry, Pusan National University, Yangsan, Republic of Korea
}

Although intentional replantation is frequently used as a treatment modality for endodontic problems, severe periodontal involvement has usually been regarded as a contraindication. However, there are some studies suggesting that intentional replantation could be a successful treatment alternative for periodontally involved teeth. This paper reports the treatment of a tooth with severe periodontal involvement using intentional replantation. The tooth, which had had root canal therapy due to endodontic-periodontal combined lesion but showed extensive bone loss, was gently extracted and replanted after thorough debridement of the root surface. By intentional replantation, a tooth with severe periodontal involvement in this case could be preserved, without extraction, over the course of a 3-year follow-up period. (J Dent Rehabil Appl Sci 2019;35(2):98-104)

Key words: alveolar bone loss; periodontal attachment loss; periodontal diseases; root canal therapy; tooth replantation

\begin{abstract}
서론
만성 치주염은 세균 감염으로 인한 치조골 상실과 치 주낭 발생을 야기하는 질환이다. ${ }^{1}$ 대표적인 원인은 치석, 변연부가 불량한 보철물, 흡연, 조절되지 않는 전신질환 그리고 유전 인자 등이며, 적절한 치료 없이는 치아 상실 과 저작 불편감 등이 초래될 수 있다. ${ }^{2}$ 치주치료의 일차 적인 목적은 치주 질환으로 인해 상실된 조직의 회복이 며, 여기에는 비외과적 또는 외과적 방법이 존재한다. 그 러나 치근단을 넘어서까지 치주 조직이 파괴된 치아는 예 후가 불량하다고 판단되며, 발치를 고려하는 경우가 많 다. 그 이유는 치주염을 유발하는 치석과 같은 국소 인자 를 발치 하지 않고, 기구 조작만으로 치근단 영역까지 도 달하여 완전히 제거하는 것이 어렵고 치주치료 도중 또 는 이후 원치 않는 동요도가 증가할 수 있기 때문이다. ${ }^{3}$
\end{abstract}

*Correspondence to: Eun-Young Kwon

Clinical assistant professor, Dental Clinic Center, Pusan National University Hospital, Gudeokro 179, Seogu, Busan, 49241, Republic of Korea Tel: +82-51-240-7429, Fax: +82-51-240-7706, E-mail: betteryoung@hanmail.net Received: February 2, 2019/Last Revision: March 6, 2019/Accepted: April 27, 2019
이 때 시야 확보와 기구 조작의 접근성을 향상 시키기 위해 고려해 볼 수 있는 것이 의도적 재식술이며, 이는 치 아를 의도적으로 발치하여 치근면을 처치 후 다시 원래 의 발치와로 재삽입하는 술식이다. ${ }^{4}$ 의도적 재식술의 적 응증은 대부분 근관 치료의 실패로 인한 경우이며, 중등 도 이상의 치주 질환을 보이는 치아에서는 흔히 추천되 지 않는다. 또한 장기간의 성공적인 결과를 위해서는 건 강한 치주조직이 필수조건으로 알려져 있다. ${ }^{5}$ 그러나, 일 부 연구들에서 중도 치주염에 이환된 치아를 보존 하기 위해서 의도적 재식술을 이용하여 성공적인 결과를 보고 한 바가 있다. ${ }^{6-10}$

이전의 연구들은 대개 발치 후 재식 전 enamel matrix derivative나 골대체재와 같은 재생 처치를 위한 재료를 사용하거나 테트라싸이클린 등으로 치근면 처치를 시행 하였다. 본 연구에서는 근관-치주 복합 병소로 진단 후

Copyright C 2019 The Korean Academy of Stomatognathic Function and Occlusion. (c) It is identical to Creative Commons Non-Commercial License. 
근관치료를 선행하였으나 지속적인 광범위한 골소실을 보인 중도 치주염에 이환된 치아를 의도적으로 발치 후 부가적인 재생 물질이나 약물의 사용 없이 치근면에 침 착된 원인 인자만을 제거하고 재식하여 보존할 수 있었 던 증례를 보고하고자 한다.

\section{증례보고}

57세의 여자 환자가 하악 우측 견치(\#43) 부위에서 치 은 부종, 출혈 등의 불편감이 느껴진다는 주소로 내원하 였다. 임상 검사 결과 \#43 부위의 원심부 치은 부종, 그리 고 협측에서 근심부에서 원심부에 이르는 $8 \mathrm{~mm}$ 이상의 깊은 치주낭이 관찰되었다(Fig. $1 \mathrm{~A})$. 또한 1 도의 동요도 와 전기 치수 검사상 음성 반응을 보였다. 방사선 사진상 \#43 부위의 근심부에서 원심부에 이르는 골흡수 양상이 이미 치근단을 넘어서 있음이 관찰되었다(Fig. 2A). 본 증 례에서 해당 치아는 전기 치수 검사에서 음성 반응을 보 였으나 치조정에서 치근단 부위까지 연장된 광범위한 치 주 조직의 파괴가 동반되어 관찰되었다. 따라서 근관 기 원만의 치근단 병소가 아닌 근관-치주 복합 병소로 진단 하였다. 치조정에서부터 치근단 부위까지 골파괴가 연장 되어 있어 발치를 고려할 수도 있으나, 구강 위생 관리 능
력이 높은 환자가 치아 보존에 대한 의지를 나타내었고, 해당 치아가 하악 견치인 전치부 단근치이므로 구치부 다근치에 비해 근관치료나 치주치료 결과에 대한 예후가 양호할 것이라 판단하여 우선 보존하기 위한 치료계획을 수립하였다. 이에 비외과적 치주치료와 근관치료를 시행 하고 일차적인 치유를 기다린 후 잔존한 골 결손부는 외 과적 치료치료를 통해 해결하고자 계획하였다. 치은의 부종 및 발적을 제거하기 위해 치석제거술과 치근활택술 을 먼저 시행하고 이후 근관치료를 진행하였다(Fig. 2B, 2C) 근관치료 완료 후 3 개월 정도의 경과 관찰 기간을 가 진 후 재평가하여 필요시 치주 재생 술식을 진행하려고 했으나 환자가 내원하지 않았다.

근관치료 완료 이후 6개월이 지나서 환자가 \#43 부위 의 불편감으로 재내원하였다. 이 때 3 도의 동요도를 보이 고 있었으며, 이는 초진시 보다 동요도가 더욱 증가된 상 태였고, 치은 열구에서 삼출물이 관찰되었다(Fig. 1B). 방 사선 사진상 \#43 부위뿐만 아니라 \#42의 원심 부위까 지 연장된 광범위한 골흡수가 관찰되었다(Fig. 2D). 이는 초진에서 관찰되었던 것보다 오히려 골흡수 범위가 더 욱 확대된 상태로 근관치료 만으로는 치아 주위의 골흡 수를 해결할 수 없고, 치주 조직에 대한 처치 없이는 치아 를 보존할 수 없음을 확인할 수 있었다. \#42, 43 부위의
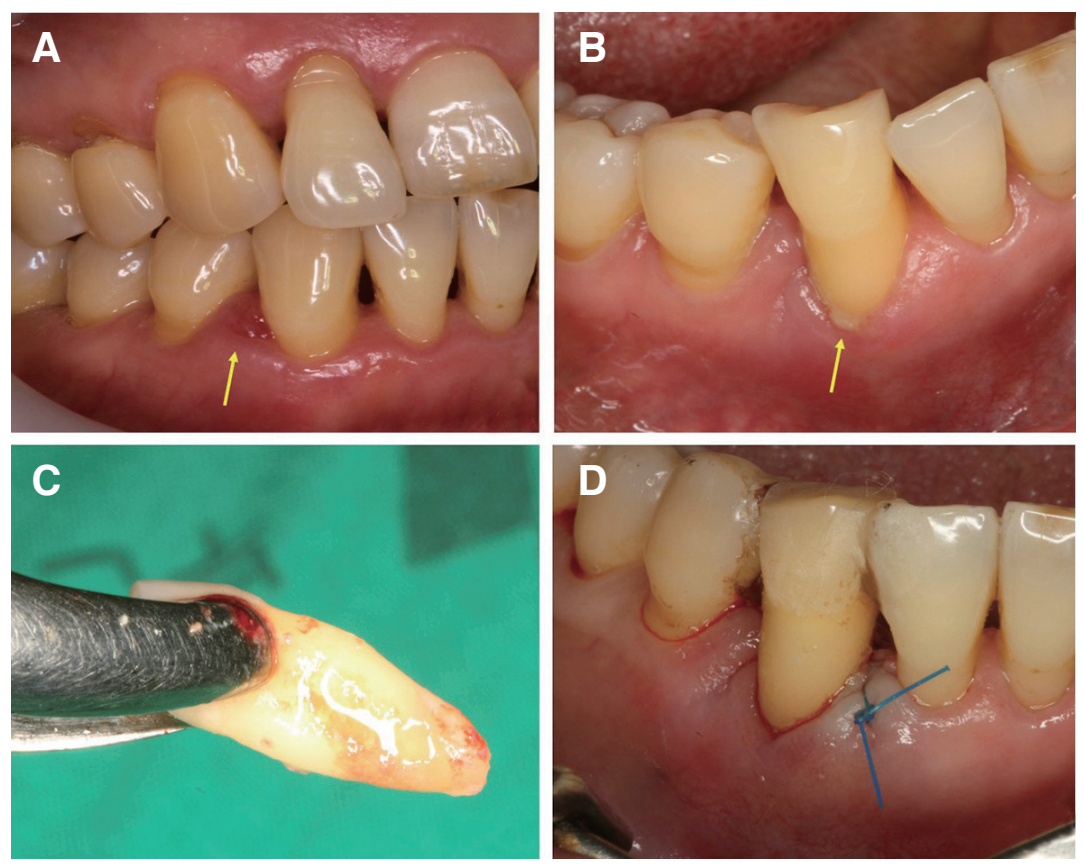

Fig. 1. Clinical view of case. (A) Gingival swelling and redness of the mandibular right canine were detected at first visit, (B) Pus discharge from gingival sulcus was found at 6 month after root canal therapy, (C) Calculus and inflamed tissue were observed during intentional replantation, (D) Replanted tooth was splinted with adjacent teeth and occlusal adjustment was performed. 


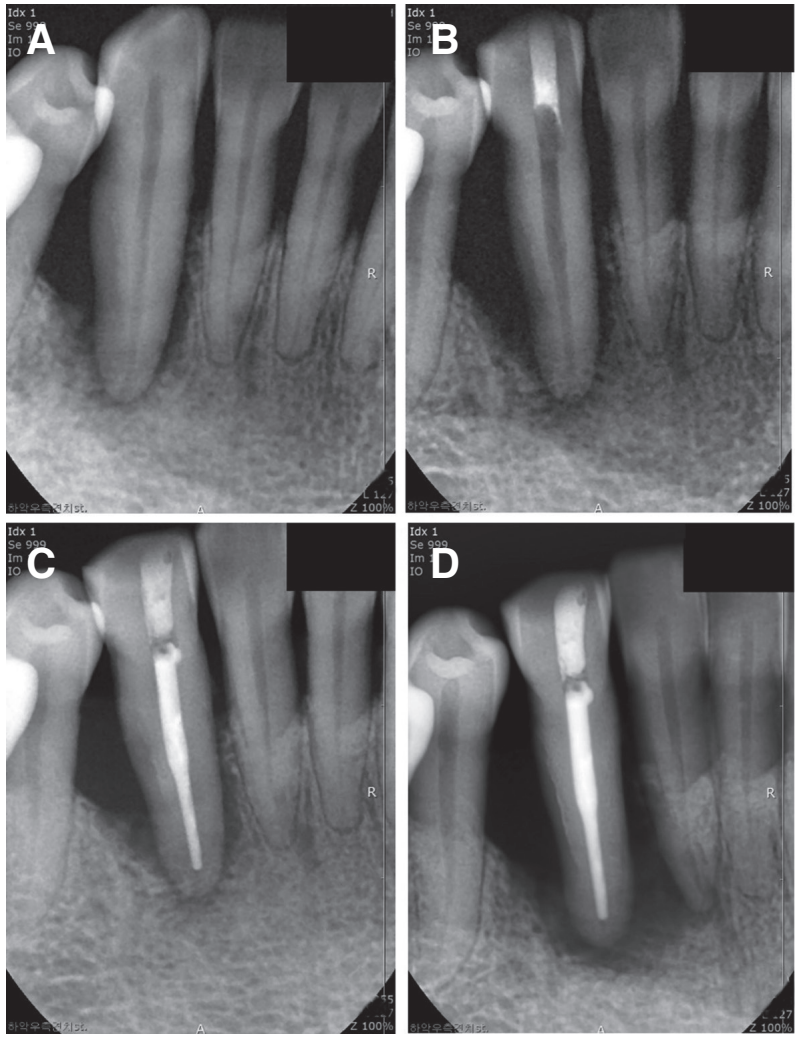

Fig. 2. Intraoral periapical radiograph of case. (A) Marginal bone loss extended to apical area in the mandibular right canine was observed at initial visit, (B) During root canal therapy, (C) Immediately after root canal filling, (D) Severe alveolar bone loss extended to adjacent tooth was found at 6 month after root canal therapy.

발치 및 보철치료를 일차적으로 고려할 수 있으나, 최후 의 치료 수단으로 \#43 부위의 의도적 재식술을 계획하였 다. 그 이유는 치주 조직의 재생을 위해서 무엇보다 치근 면에 축적된 원인 인자인 치태, 치석 등을 완전히 제거해 야만 염증이 소실되고 골재생이 기대될 수 있는데, 발치 하지 않고 판막만 거상하여 시행하는 외과적 치주치료로 는 \#43 부위의 치근단 주위에서 원인 요소들을 완벽하게 제거하기 어렵다고 판단하였기 때문이다. 또한 통상적인 치주수술 방법으로 국소 인자가 모두 제거 되지 못한 채 로 골 이식술이나 조직 유도 재생술 등의 재생형 골수술 을 시행하는 것은 성공적인 치료 결과를 내기 어렵다고 판단하였다. 따라서 부가적인 재료나 술식의 도움 없이 오직 의도적으로 발치 후 치근 표면에 침착된 국소 인자 의 완전한 제거만을 통한 치유를 목표로 시행하기로 계
획하였다. 국소마취 후 발치 겸자만으로 조심스럽게 발 치를 시행 후 구강외에서 치근 표면에 침착된 치석 및 괴 사된 조직을 초음파 기구로 제거하였으며, 구강외에서 조작하는 시간을 최소화 하도록 하였다(Fig. 1C). 발치와 내부는 생리 식염수로 세척한 후 최대한 발치와 측벽은 건드리지 않도록 주의하면서, 발치와 기저부 쪽에서 관 찰되는 육아조직만을 조심스럽게 제거하였다. 시술 직전 3 도의 동요도를 보인 치아였으므로 시술 이후 고정이 필 요하다고 판단하여, 치아를 재위치 시킨 후 자가중합형 복합레진 시멘트(Superbond C\&B, Sun Medical, Shiga, Japan)를 이용하여 인접치에 고정시켰다(Fig. 1D). 또한 교합 간섭이 발생하지 않도록 교합조정을 시행하였다.

술후 6 개월째 치은의 부종이나 삼출물 등은 관찰되 지 않았고(Fig. $3 \mathrm{~A}$ ), 술후 1년째에도 치은의 염증은 관찰 되지 않았고 방사선 사진상 신생골 형성이 확인되어 고 정을 위해 이용된 자가중합형 복합레진 시멘트를 조금 씩 제거하기 시작하였다(Fig. $3 \mathrm{~B}$ ). 이후 3년의 경과 관찰 기간 동안 환자의 불편감, 탐침시 출혈이나 부종은 관찰 되지 않았고, 치주낭 깊이는 $3 \mathrm{~mm}$ 이하로 유지되었다 (Fig. 3C, 3D). 방사선 사진 상 술후 6개월째부터 \#43 및 \#42 치근단 주위의 재생된 골이 관찰되었다(Fig. 4A). 또 한 3 년간의 경과 관찰 기간 동안 치근단 방사선 사진상 \#43,42 주위의 재생된 골이 안정적으로 유지됨을 확인하 였다(Fig. 4B, 4C, 4D).

\section{고찰}

의도적 재식술은 기존의 치주 치료시 기구 접근이 불가 능한 부위를 구강외에서 눈으로 직접 보면서 인접 치주 조직의 손상 없이 기구 조작을 완벽히 할 수 있게 하므로, 기존 치주치료의 대안 중 하나가 될 수 있을 것이다. 만일 의도적 재식술 중 발치된 치아의 치근을 관찰시 건전한 치주인대 조직이 존재한다면 치근 표면을 건드리지 않는 것이 일반적으로 추천된다. ${ }^{5}$ 그러나 괴사된 치주 인대와 백악질이 치근 표면에 존재하는 것이 확인된다면 제거하 는 것이 추천되는데, 이는 제거되지 못한 조직들이 추후 의 감염원으로 작용 할 수 있고 더 나아가 치근 흡수나 유착을 일으킬 수 있기 때문이다. ${ }^{8,11,12}$ 본 증례에서도 의 도적 재식술시 장기적으로 진행된 만성 치주염에 의해 치 근 표면에서 괴사된 조직이 관찰되었으며, 이로 인한 치 근 흡수나 유착이 우려되어 모두 제거하였다.

일부 임상가들은 발치와 내부를 재식 하기 전에 깨끗 

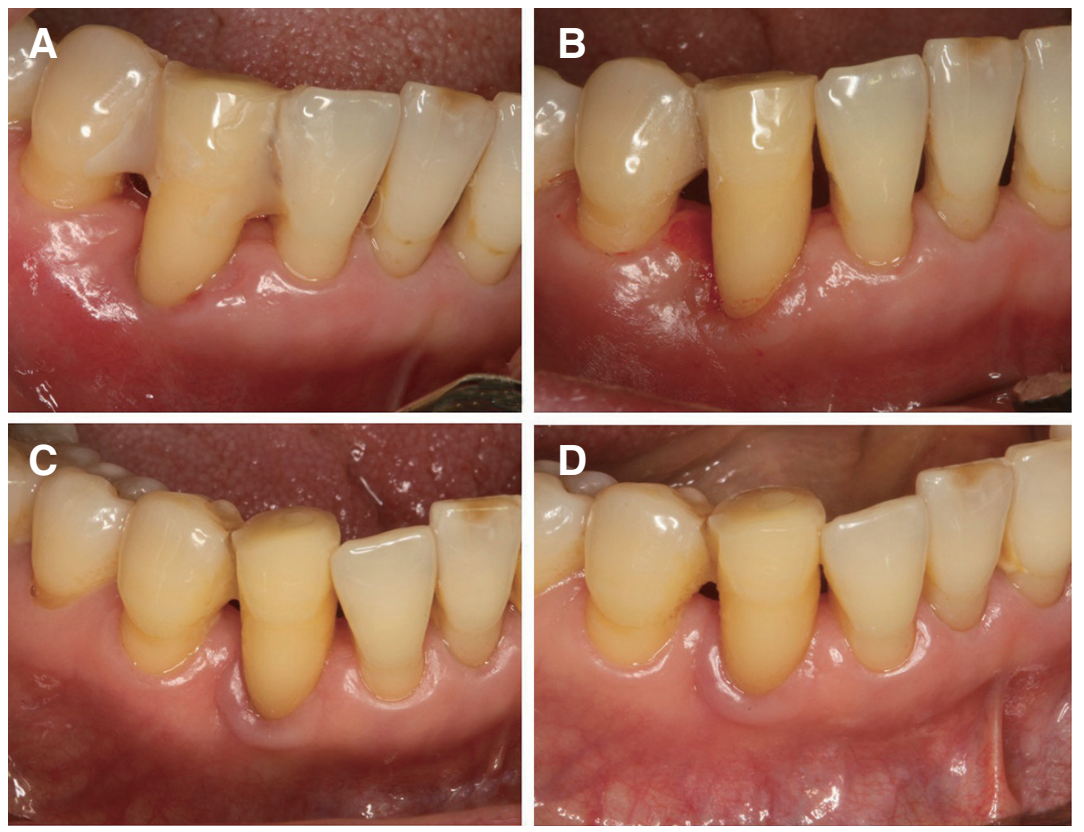

Fig. 3. Clinical view of case during followup period. (A) Gingival swelling and pus discharge disappeared at 6 month after intentional replantation, (B) Decreased mobility was confirmed and material used for splinting was removed partially at 1 year after intentional replantation, (C) Two year after intentional replantation, (D) Three year after intentional replantation.
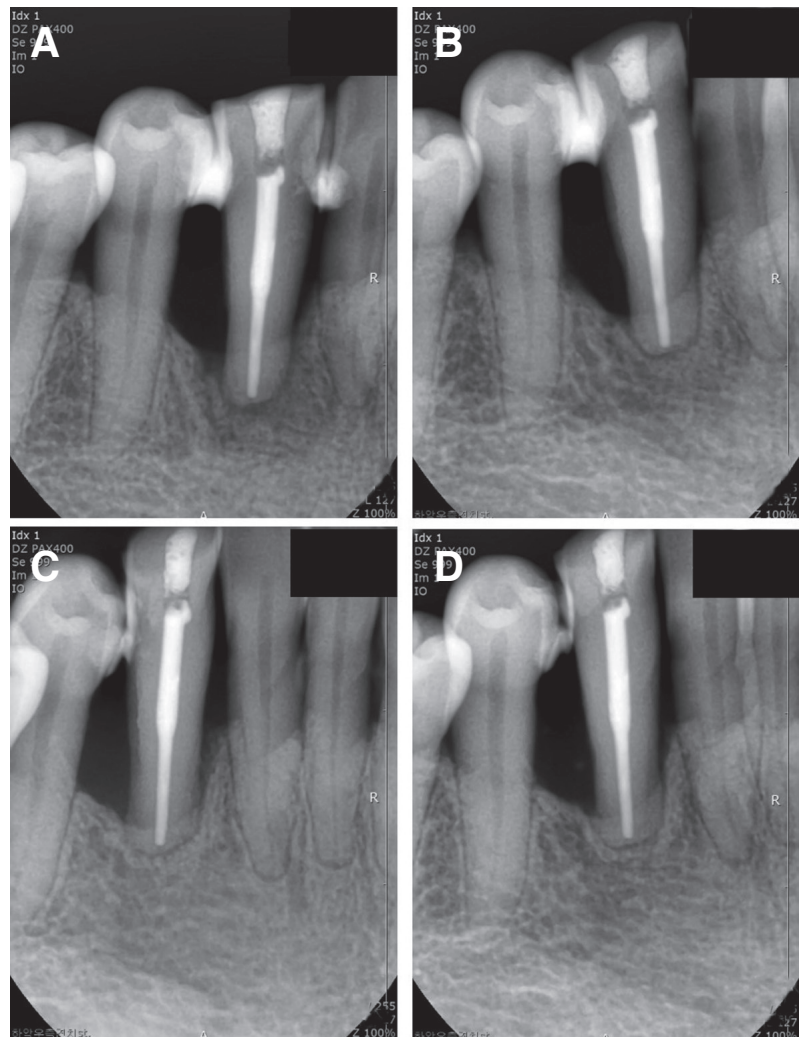

Fig. 4. Intraoral periapical radiograph of case during follow-up period. (A) Alveolar bone regeneration around replanted tooth was found at 6 month after intentional replantation, (B) One year after intentional replantation, (C) Two year after intentional replantation, (D) Three year after intentional replantation.
하게 소파하는 것을 선호하는데, 이는 괴사된 조직이 치 유와 골 형성을 방해할 수 있기 때문이다. ${ }^{13}$ 그러나 발치 와 내면 벽을 건드리지 않고 오직 생리 식염수로만 세척 하는 것이 추천되기도 하는데, 이는 발치와 내면 벽을 건 드리면 유착의 위험도를 증가시키기 때문이다. ${ }^{5}$ 본 연구 에서는 치아를 재식 하기 전 생리 식염수로 발치와를 세 척하였고 만성 치주염으로 인해 발치와 기저부에 존재하 던 육아조직은 재감염 방지를 위해 제거하였다. 이때 가 급적 내면 벽 부위는 건드리지 않도록 조심하였고, 기저 부의 오염된 육아조직은 완전히 제거함으로써 치근과 비 교적 깨끗한 치조골이 직접적으로 접촉할 수 있는 환경 을 만들어 주도록 노력하였다.

재식한 치아를 인접치에 고정하는 것이 항상 필요하다 고 고려되는 것은 아니나, 만일 의도적 재식술로 치료한 치아가 증가된 동요도를 보인다면, 치주 조직 재생을 방 해하여 치유에 심각한 영향을 끼칠 수 있다. 또한 염증이 존재한다면 동요도의 존재가 상피 부착의 치근단 방향으 로의 이주에 영향을 끼칠 수 있기 때문이다. ${ }^{14,15}$ 본 연구에 서 의도적 재식술 직후 인접치에 자가중합형 복합레진 시 멘트를 이용하여 고정을 시행하였는데, 이는 치조골 지 지가 이미 $50 \%$ 이상 소실된 상태였고 술전부터 3도 정도 의 동요도가 관찰된 단근치였기 때문이다. 또한 고정 직 후 교합 조정을 시행하여 교합성 외상이나 교합 간섭이 없음을 확인하였다. 이후 경과 관찰기간 동안 임상 검사 
상 연조직이 염증 없이 건강하게 유지되는 것을 확인하 고 방사선 사진상 신생골 형성이 일어나는 것을 관찰한 후 자가중합형 복합레진 시멘트를 단계적으로 제거하기 시작하였다.

최근 의도적 재식술을 시행하면서 치주 재생 술식을 함 께 이용하는 것이 많이 소개되고 있는데, enamel matrix derivative나 골대체재 등이 대표적으로 쓰이며 차단막을 이용하기도 한다. ${ }^{9,10,16}$ 본 증례에서는 재생 술식을 이용 하지는 않았으며, 치근 표면에서 치석 제거술 및 치근 활 택술을 시행하고 발치와 내면을 처치한 후, 재식만을 시 행하였다. 추후 다른 증례에서 재생 능력을 극대화 하기 위해 치주 재생 술식을 고려해 볼 수 있을 것이며, 이 때 에도 전제 조건은 치근면과 발치와 내부의 적절한 처치일 것이다.

재식된 치아에서 유착은 치아 경조직의 점진적 흡수와 골로 대체되는 흔한 합병증이며, 이후의 치근 흡수는 장 기간의 예후에 영향을 미칠 수 있다. ${ }^{11}$ 이러한 유착을 방 지하려면 무엇보다 건전한 치주 인대의 손상을 줄여야 한다. 본 증례에서도 구강외에서 기구 조작 시간을 8 분 이내로 최소화했으며, 치근 표면에서 괴사된 조직만을 제거하고 발치와 내벽에서도 비교적 건전한 조직은 건드 리지 않도록 노력하였다.

의도적 재식술 이후 임상 검사시 치주낭 깊이의 감소 가 확인되고 방사선 사진상 신생골 형성 등이 관찰이 되 어야 성공적인 결과를 얻었다고 볼 수 있다. 이 때 성공적 인 결과를 얻기 위해서는 치주인대의 생활력 보존이 필수 적인데, 이는 치주인대 내의 미분화 세포가 전구 세포로 작용하여 백악질 및 치조골의 재생을 유도하기 때문이 다. ${ }^{17,18}$ 본 증례에서도 의도적 재식술을 시행하는 동안 건 전한 치주인대를 최대한 보존하고자 노력하였고, 그 결 과 3 년간의 추적 관찰 기간 동안 치근단 방사선 사진상 해당치아를 포함한 인접치 주변까지 치조골을 포함한 치 주조직의 재생이 일어남을 관찰하였다. 술전 임상 검사 시 해당 치아에서 $10 \mathrm{~mm}$ 이상의 치주낭 깊이를 보였던 부위가 $3 \mathrm{~mm}$ 이하로 유지되었고, 부종 및 발적 등의 치 은 염증이 재발되지 않음을 확인하였다. 의도적 재식술 을 통해 다수치 발치 및 보철 치료를 시행하지 않고 해당 치아 및 인접치까지 보존할 수 있었다.

\section{결론}

자연치를 보존하고자 하는 것은 보존적 치료의 일차적
목적이다. 그러나 중등도 이상으로 치주 조직이 파괴된 경우, 기존의 비외과적 또는 외과적 치주치료로 해결되 지 못해서 발치 및 보철치료로 연결되는 경우가 많다. 이 때, 의도적 재식술을 통해 접근이 어려운 부위에서 시야 확보 및 기구 조작을 용이하게 하여 치아를 보존할 수 있 도록 도와줄 수 있으므로 발치 전 최후의 수단 중 하나로 고려해 볼 수 있을 것이다.

\section{Acknowledgements}

본 연구는 2019년도 부산대학교병원 임상연구비 지원 으로 이루어졌음.

\section{ORCID}

Youn-Kyung Choi https://orcid.org/0000-0003-1491-2986

Kyoung-Hwa Jung https://orcid.org/0000-0002-8305-0016

Ju-Youn Lee https://orcid.org/0000-0002-0772-033X

Ji-Young Joo https://orcid.org/0000-0002-4050-5797

Hyun-Joo Kim https://orcid.org/0000-0001-7553-6289

Eun-Young Kwon https://orcid.org/0000-0001-9555-0360

\section{References}

1. Armitage GC. Development of a classification system for periodontal diseases and conditions. Ann Periodontol 1999;4:1-6.

2. Berezow AB, Darveau RP. Microbial shift and periodontitis. Periodontol 2000 2011;55:36-47.

3. Wang J, Jiang Y, Chen W, Zhu C, Liang J. Bacterial flora and extraradicular biofilm associated with the apical segment of teeth with post-treatment apical periodontitis. J Endod 2012;38:954-9.

4. Grossman LI. Intentional replantation of teeth: a clinical evaluation. J Am Dent Assoc 1982;104:6339.

5. Kratchman S. Intentional replantation. Dent Clin North Am 1997;41:603-17.

6. Lu DP. Intentional replantation of periodontally involved and endodontically mistreated tooth. Oral Surg Oral Med Oral Pathol 1986;61:508-13.

7. Demir B, Demiralp B, Guncü GN, Uyanik MO, Cağlayan F. Intentional replantation of a hope- 
less tooth with the combination of platelet rich plasma, bioactive glass graft material and non-resorbable membrane: a case report. Dent Traumatol 2007;23:190-4.

8. Demiralp B, Nohutçu RM, Tepe DI, Eratalay K. Intentional replantation for periodontally involved hopeless teeth. Dent Traumatol 2003;19:45-51.

9. Tözüm TF, Keçeli HG, Serper A, Tuncel B. Intentional replantation for a periodontally involved hopeless incisor by using autologous platelet-rich plasma. Oral Surg Oral Med Oral Pathol Oral Radiol Endod 2006;101:e119-24.

10. Baltacioglu E, Tasdemir T, Yuva P, Celik D, Sukuroglu E. Intentional replantation of periodontally hopeless teeth using a combination of enamel matrix derivative and demineralized freeze-dried bone allograft. Int J Periodontics Restorative Dent 2011;31:75-81.

11. Hammarström L, Blomlöf L, Lindskog S. Dynamics of dentoalveolar ankylosis and associated root resorption. Endod Dent Traumatol 1989;5:163-75.
12. Andreasen JO. Analysis of pathogenesis and topography of replacement root resorption (ankylosis) after replantation of mature permanent incisors in monkeys. Swed Dent J 1980;4:231-40.

13. Sharma NK, Duggal MS. Replantation in general dental practice. Br Dent J 1994;176:147-51.

14. Kehoe JC. Splinting and replantation after traumatic avulsion. J Am Dent Assoc 1986;112:224-30.

15. Ferencz JL. Splinting. Dent Clin North Am 1987; 31:383-93.

16. Ryana HK, Srinath R, Prakash S. Surgical re-entry of an intentionally replanted periodontally compromised tooth treated with platelet rich fibrin (PRF): Hopeless to hopeful. J Clin Diagn Res 2016;10: ZD01-4.

17. Meyer JR. The regenerative potential of the periodontal ligament. J Prosthet Dent 1986;55:260-5.

18. Nyman S, Gottlow J, Karring T, Lindhe J. The regenerative potential of the periodontal ligament. An experimental study in the monkey. J Clin Periodontol 1982;9:257-65. 


\section{중도 치주염에 이환된 치아의 보존을 위한 의도적 재식술을 통한 치료: 증례보고}

\section{최윤경 ${ }^{1}$ 정경화 ${ }^{1}$, 이주연 ${ }^{2}$, 주지영 ${ }^{2}$, 김현주 ${ }^{2}$, 권은영 ${ }^{1 *}$}

${ }^{1}$ 부산대학교병원 치과진료센터

${ }^{2}$ 부산대학교 치의학전문대학원 치주과학교실

의도적 재식술은 흔히 근관 치료가 실패한 경우 사용되는 치료법이나, 중도의 치주 질환에 이환된 치아에서는 대개 추천 되지 않는다. 그러나, 일부 연구들은 의도적 재식술을 이용하여 치주 질환에 이환된 치아를 성공적으로 치료한 것을 보고 한 바가 있다. 본 연구에서는 중도 치주염에 이환된 치아를 의도적 재식술을 이용하여 치료한 증례를 보고하고자 한다. 해당 치아는 근관-치주 복합 병소로 진단 후 근관치료를 선행하였으나 광범위한 골소실을 나타냈으며, 이에 의도적으로 발치 후 치근 표면의 국소 인자를 완전히 제거한 후 재식하였다. 의도적 재식술을 이용하여 본 증례에서 중도 치주염에 이환된 치아를 발치하지 않고 3 년간의 경과 관찰 기간 동안 보존할 수 있었다.

(구강회복응용과학지 2019;35(2):98-104)

주요어: 치조골 소실; 치주 부착 소실; 치주염; 의도적 재식술

*교신저자: 권은영

(49241)부산시 서구 구덕로 179 부산대학교병원 치과진료센터 치주과

Tel: 051-240-7429 | Fax: 051-240-7706 | E-mail: betteryoung@hanmail. net

접수일: 2019년 2월 2일 | 수정일: 2019년 3월 6일 | 채택일: 2019년 4월 27일 